\title{
REVIEW
}

\section{EN NY POLITISK ANTROPOLOGI FOR SYDASIEN}

\author{
KENNETH NIELSEN
}

JONATHAN SPENCER: Anthropology, Politics and the State: Democracy and Violence in South Asia. Cambridge: CUP 2007. ISBN 13:9780521777469 (pb). Pris: $£ 15.99$

LUCIA MICHELUTTI: The Vernacularisation of Democracy: Politics, Caste and Religion in India. London, New York \& New Delhi: Routledge 2008. ISBN 978-0-415-46732-2 (hb). Pris: \$95.

Er man interesseret i politisk antropologi, og har man samtidig Sydasien som empirisk felt, gør man klogt i at følge med i, hvad der rør sig på de britiske øer for tiden. Her produceres en række interessante antropologiske studier af „det politiske" i Sydasien, som kredser omkring nye og fremvoksende forskningsfelter inden for den politiske antropologi.

En brugbar introduktion til den ny politiske antropologi kan man finde i Jonathan Spencers bog Anthropology, Politics and the State: Democracy and Violence in South Asia. Bogen var for nylig genstand for diskussion på et lille seminar for folk med forskningsinteresse i sydasiatisk politik ved Universitetet i Oslo, denne anmelders arbejdsplads. Her vakte bogen ikke større begejstring. Spencer bidrager for det første ikke med nogen ny empirisk funderet forskning, og for det andet finder han en god del af sin teoretiske inspiration i europæisk tænkning. Begge dele ser ægte regionalister på med en vis skepsis og det ikke uden grund. Men som et bidrag til den politiske antropologi om Sydasien fungerer bogen ikke desto mindre alligevel.

Spencers udgangspunkt er den politiske antropologis bortgang og pludselige genopstandelse. I 1980'erne, siger Spencer, døde den politiske antropologi en stille om end mystisk død, og det er først i de senere år, at antropologer igen er blevet tilstrækkeligt opmærksomme på den afgørende rolle, det politiske spiller i såvel konstruktionen af sociale relationer som i folks verdensanskuelser. 
At erklære politisk antropologi for død og genopstanden kan dog synes noget overdrevet. De fleste daterer den politiske antropologis undfangelse til udgivelsen af Fortes og Evans-Pritchards African Political Systems i 1940, hvor statsløse samfunds politiske strukturer blev gjort til antropologisk genstandsfelt. 1950'erne og 1960'erne bød på en periode med konsolidering og modning af en egentlig antropologisk tilgang til det politiske qua banebrydende værker af blandet andet F.G. Bailey, Victor Turner, Boissevain, Abner Cohen og Frederik Barth, hvoraf flere stadig fremstår som antropologiske klassikere. Bailey i særdeleshed var engageret $i$ at skabe en antropologisk værktøjskasse, hvormed man kunne begribe det politiske antropologisk, inspireret af, men dog væsensforskellig fra, fx statsvidenskabens. I 1970'erne var politisk antropologi blevet en veletableret disciplin med et eget vokabular bestående af begreber som faktionalisme, patron-klientrelationer, brokerage, socialt drama, political prizes and values, arena og felt, med hvilke antropologien tilnærmede sig en forståelse af politiske processer og konkurrence, særligt på mikroniveau.

Mens man kan give Spencer ret i, at det meste af dette vokabular forsvandt fra den antropologiske diskurs i 1980'erne, skyldes dette snarere den transformationsproces, antropologien generelt gennemgik under postmodernismens indflydelse, og ikke en egentlig likvidering af den politiske antropologi i særdeleshed. Det politiske var så absolut til stede i denne transformationsproces, ofte i form af en kritik af dominans og magtens virkning $i$ al sin usynlige og uigennemskuelige mangfoldighed, fx inspireret af Foucaults arbejder eller Edward Saids kritik af orientalismen. I kølvandet på studier af magt fulgte studier af modstand, hvoraf nogle af James Scotts værker fremstår som moderne om end meget kritiserede klassikere fra perioden. Til 1980'ernes (historiske) politiske antropologi hører også det succesfulde indiske Subaltern Studies-projekt, lanceret af historikeren Ranajit Guha. Også Subaltern Studies-projektet peger på en afgørende transformation i studiet af det politiske. Udsprunget af en vis utilfredshed med den klassiske marxisme, som også den politiske antropologi i Europa havde været tæt knyttet til i 1970'erne, fandt Guha et al. ny inspiration, først hos Gramsci og senere hos Foucault, Said, Derrida og diskursanalyse.

Mens rygterne om den politiske antropolgis død anno 1980 således synes overdrevne, må man give Spencer ret i, at den på grund af en langvarig transformationsproces i dag fremstår i en ny inkarnation, som gør den næsten uigenkendelig. Det er denne nye inkarnation, Spencer introducerer os til, for leder man efter en historisk gennemgang af feltet, leder man til dels, om end ikke helt, forgæves. Den kritiske dimension, der er inspireret af 1980'ernes postmodernisme, er stadig til stede, men ikke i en radikal social(de)konstruktivistisk udgave. Dette er en velkommen udvikling, da man dermed får elimineret de mest mekaniske og 
forudsigelige og derfor i længden også kedelige Foucault-inspirerede analyser af magtens og diskursens altomgribende virkninger og konstituerende effekt. I stedet kan vi gå mere direkte til sagen i empirisk forstand, og her introducerer Spencer os til nye temaer som demokrati, stater og politisk vold, og pluralisme. Performativitet, emotionalitet, moralitet og det politiskes „excess“ er vigtige begreber, som for øvrigt også markerer tydelig afstand til tidligere tiders mere sterile antropologiske tilgang til det politiske. Spencer giver gennem en review af samtidige tekster et brugbart overblik over den ny sydasiatiske politiske antropologi, men bogen er selvsagt empirisk noget tynd, al den stund at forfatteren ikke har ny empiri at bidrage med.

Ønsker man derimod empirisk tyngde, kan man med fordel kaste sig over antropologen Lucia Micheluttis bog The Vernacularisation of Democracy: Politics, Caste and Religion in India, som er første bind i den ny serie „Exploring the Political in South Asia“, der er redigeret af antropologen Mukulika Banerjee. Michelutti har gjort sit feltarbejde blandt folk fra Yadav-kasten, en af Nordindiens politisk mest indflydelsesrige kaster. Her undersøger Michelutti, hvorledes demokratiets værdier og praksisser rodfæstes i lokale sociale og kulturelle praksisser og dermed bliver gjort til en del af folks bevidsthed, en proces, Michelutti kalder „vernacularisation“. Styrken ved denne tilgang er, at Michelutti dermed afdækker ikke blot, at og hvordan politiske ideer rodfæstes i praksis og bevidsthed, men også hvilke sociale konsekvenser denne proces kan have. Resultatet er en bog, som derfor faktisk mange steder ikke handler om politik, men snarere om de sociale felter, som politiske ideer rodfæstes i, og som både giver form til og formes af det politiske. Hermed bevæger vi os ind på klassiske antropologiske temaer, for eksempelvis slægtskab, kaste, religiøsitet eller ægteskabspraksisser er sociale aspekter, som det politiske interagerer med. Særlig interessant bliver det, når Michelutti udfolder, hvordan politik og demokratiske ideer betyder, at folk fra Yadav-kasten redefinerer ikke blot sig selv, men også deres guder, deres mytiske ophav, deres plads i kastehierarkiet og deres religiøsitet. Her ville det have været oplagt at trække på den antropologiske litteratur om traditioners (gen)opfindelse, men denne lille undladelsessynd er nem at tilgive. For Michelutti formår generelt at gøre os empirisk meget klogere på Yadavs og nordindisk politik, samtidig med at hun giver os interessante og mere bredt anvendelige teoretiske perspektiver. Så selv om bogen umiddelbart vil have størst appel til folk med Sydasien som empirisk felt, rammer den bredere.

Spencers generelle introduktion og Micheluttis monografi supplerer hinanden fint og udgør til sammen et læsværdigt par. Andet bind af serien „Exploring the Political in South Asia" er allerede på gaden i form af en antologi redigeret af Christophe Jaffrelot og Sanjay Kumar om plebejernes indtog i indisk politik. 
Mens den så absolut er af interesse for folk, der er engageret $\mathrm{i}$ indiske politiske forhold, har den begrænset relevans for antropologer uden interesse i regionen. I mellemtiden har Michelutti forladt Nordindien for i stedet at kaste sig ud i et studium af socialismens genfødsel i Venezuela under Hugo Chavez. Det bør åbne for interessante komparative aspekter i bedste antropologiske tradition. 